\title{
The Attitudes and Opinions of Tutees and Tutors Towards Using Cross-Age Online Tutoring*
}

\author{
Ahmad Almassaad, Khaled Alotaibi \\ King Saud University, Riyadh, Saudi Arabia
}

\begin{abstract}
The research aims to identify the attitudes and opinions of tutees and tutors at King Saud University towards using cross-age online tutoring. An electronic survey and interviews were used to collect the data required for this study. A descriptive analysis was used as a research methodology. Thirty participants in this research were asked to complete a five-point Likert scale survey, which consists of 28 items, classified in three main categories; and two items as probe statements. Also, 17 participants in this research were asked to answer the interview open-ended questions. The validity and reliability of the survey were ensured. Statistical treatments, such as percentages, means, frequencies and analysis of the ANOVA (analysis of variance) variance were also included. The results reflected the positive attitudes of the tutees and tutors towards using cross-age online tutoring. Moreover, results showed no difference in their attitudes towards using the system among the tutees in terms of academic levels or specializations.
\end{abstract}

Keywords: cross-age online tutoring, online tutoring, attitude, tutees, tutors

\section{Introduction}

The rapid growth of ICT (information communications technology) brought about many changes in all areas of our lives, as well as in the teaching process. In addition, it is obvious that there are many obstacles facing today's education. There is also a critical lack of qualified ICT teachers and students often need a great deal of extra assistance and practice in ICT applications which teachers cannot adequately provide on an ongoing and daily basis, because classrooms are getting larger these days.

In recent years, information technology has begun to permeate peer learning in various ways. With the increased access to affordable technology, the opportunity to deliver educational contents through electronic media has become even greater. Most of those who use such services are adolescent and adult learners (Weiss, 2007, p. 16).

As the concept of peer tutoring has developed over the past years resulting in many different types and formats, defining peer tutoring has become more difficult (Topping, 1996). There are a number of definitions

\footnotetext{
*Acknowledgement: The authors extend their appreciate to the Deanship of Scientific Research at King Saud University for funding the work through the research group project No. RGP-VPP-084.

Ahmad Almassaad, assistant professor, Education College, King Saud University.

Khaled Alotaibi, associate professor, Teachers College, King Saud University.
} 
which can be distinguished in relation to typical characteristics of the peer tutoring setting. Depending upon contextual circumstances, peer tutoring groups may be of the same age or cross-age, small or large, fixed or reciprocal, face-to-face or online and preliminarily trained or untrained. The peer tutoring concept, therefore, draws on a wide-ranging review of literature and discussion (Smet, 2008, p. 1).

The peer tutoring is an individualized activity designed to meet the educational needs of all members of a classroom. It is intended to enable students to assist each other in learning a new skill (Auxter, 2007). Moreover, it is a successful system for traditional learning because of the personal one-on-one interaction between the tutor and the student (Prensky, 2002). However, when peer tutoring is blended with technology, the impact on the educational process should be even greater and it should enhance mastery of educational content and increase students' self-esteem (Thompson, 2007).

Peer tutoring and cross-age tutoring are two student-to-student tutoring methods (Topping \& Ehly, 1998). In this respect, peer learning can be defined as the acquisition of knowledge and skills through active helping and supporting among status equals or matched companions (Topping \& Ehly, 1998). It occurs when both the tutor and tutee are at the same age. In cross-age tutoring, the tutor is older than the tutee (Gaustad, 1993). By contrast, cross-age tutoring involves students at different ages or grade levels, typically, though not exclusively, for the benefit of the younger student (Weiss, 2007, p. 3). It allows older students to work with younger students and provides an opportunity to teach a part of the younger students' curriculum (Muscott, 2001). In the pedagogical role, tutors support the learning process itself by providing instructions, stimulating questions, examples, feedback and motivation for the learners (Teles, Ashton, Roberts, \& Tzoneva, 2001). However, academic tutoring is a common technique that used to assist students to learn better and improve their academic performance and behavior (Weiss, 2007, p. 2). A more capable, knowledgeable and experienced peer with a supportive role is called the "tutor", while less experienced students receiving help from a tutor are called “tutees” (Topping, 1998).

\section{Reasons}

There is a growing demand on the part of educators and researchers to understand and take full advantage of the environments where the Internet and email access are essential components of a collaborative learning process (Bonk, Wisher, \& Lee, 2004). However, research into online peer tutoring remains scarce and limited to higher education only (de Vries, Kester, Sloep, van Rosmalen, Pannekeet, \& Koper, 2005; Jones, Garralda, Li, \& Lock, 2006; McLuckie \& Topping, 2004). By online tutoring, we mean that most participants are geographically isolated, but have full access to all necessary resources via their Internet connection. Materials and supporting activities will be provided electronically, and interaction will be either synchronous or asynchronous (Smet, 2008, p. 8).

Denis, Watland, Pirotte, and Verday (2004) distinguished four peripheral tutor roles: designer, 
manager/administrator, co-learner and researcher. However, Denis (2003) distinguished seven roles of an e-tutor: supporting the start-up, solving technical problems, answering content-related questions, supporting the methodological constraints (organization, working methods, affective-emotional factors, fostering communication and cooperation), enhancing metacognition (self-reflection), assessment and evaluation, and providing what she calls "pastoral care".

Lentell (2003, p. 74) suggested that,

Tutors need to have knowledge and a broad conceptual understanding of their field. They have to be effective listeners and communicators, coaches, facilitators, mentors, supporters and resources. They have to listen, to shape, to give feedback, to motivate, to direct, to appreciate — broadly to be developmental and problem-solving.

The benefits of peer tutoring (National Tutoring Association, 2010, p. 2):

First: Benefits for students

Peer tutoring:

- improves self confidence;

- improves self-esteem, as they become more successful students;

- improves academic achievement;

- improves attitudes towards the subject matter and school in general;

- encourages greater persistence in completing tasks and courses;

- $\quad$ encourages the use of appropriate and efficient learning and study strategies;

- $\quad$ provides an opportunity for individualized instruction;

- provides opportunities for questions and clarification of difficult concepts;

- provides additional review and practice of difficult material.

Second: Benefits for tutors

Peer tutoring:

- provides frequent reviews of previously learned material and helps learn new material in more advanced courses;

- encourages higher level thinking;

- $\quad$ improves subject specific knowledge and facilitates deeper understanding of subject matter;

- improves general knowledge;

- develops confidence in learning ability;

- improves motivation for studying;

- improves knowledge of learning, studying and test-taking techniques;

- builds self-esteem and creates a sense of pride in helping others;

- develops communication skills;

- provides experiences that may help with later employment or career goals;

- develops empathy for others;

- improves attitudes towards subject area;

- increases general knowledge;

- develops a sense of responsibility.

UK Center for Materials Education (2011, p. 1) reported that the group in the peer tutor's role provides a safe, supportive learning environment for the students and allows them to: 
- $\quad$ test out their understanding of difficult concepts introduced in lectures;

- develop their ideas when solving particular problems;

- $\quad$ take more responsibility for their own learning;

- $\quad$ gain confidence;

- develop key skills such as communication, cooperative problem-solving and group work;

- $\quad$ promote a better approach to learning.

\section{Studies}

Research into online peer tutoring remains scarce and is particularly limited to higher education (de Vries et al., 2005; Jones et al., 2006). It is expected that in the near future, the current technological and societal changes that require more distance learning and continuous learning will increase the chance that educators—at any level of education — will integrate online peer tutoring into their curricula. Hence, further research into the implications of introducing online peer tutoring at different educational levels is desperately needed (Smet, 2008, p. 4).

The study was conducted to determine the extent to which cross-age tutoring employed in a rural setting would produce outcomes similar to those reported in urban settings and in other countries. An experimental design within repeated measures was used to gauge the effects of cross-age tutoring on learning and retaining knowledge of fraction manipulations. Participating students were randomly assigned to one of four groups: tutors, tutees, non-tutors and non-tutees. Tutors and non-tutors were Grades 7 and 8 students at one of two small elementary schools in the same rural district. Tutees and non-tutees were Grades 3, 4 and 5 students, attending the same rural elementary school. Analyses of both knowledge gain and retention scores revealed no significant differences in the knowledge of fraction manipulations between tutors and non-tutors, tutors and tutees or tutees and non-tutees (Craig \& Craig, 2005).

Jones et al. (2006) collected transcripts of six face-to-face sessions conducted by five tutors, as well as logs of 18 online sessions by the same tutors and many of the same clients. Clients and tutors were non-native speakers of English and second language writers (all Chinese). All tutors had undergone an intensive training and a month-long apprenticeship and had at least three months job experience. Results showed considerable differences between the online and face-to-face tutoring sessions. Face-to-face interactions involved more hierarchical encounters in which tutors took control of the discourse; whereas, online interactions were more egalitarian and had more client control of the discourse. There was also more relational communication online aiming at establishing and maintaining rapport. It seems that there was more variation and room for negotiations in online sessions. The authors concluded that there are benefits in both types of interactions and that, ideally, both face-to-face and online tutoring should be used together (Jones et al., 2006).

In another study, the achievement of tutees has typically been found to improve more in structured programs of shorter duration with tutoring sessions limited to 20 to 30 minutes and when lower-level math and reading skills are addressed and evaluated on teacher-developed examinations rather than solely on standardized tests (Kalkowski, 2001). Social as well as cognitive interaction with both instructors and peers 
seems to be important to enhance active participation in and learning from online discussions (Jung, Choi, Lim, \& Leem, 2002).

One tends to see the greatest improvements in academic performance among tutors when there is a small or moderate age and skill difference between the tutor and tutee, so that both members of the pair find some cognitive challenges in their activities (Weiss, 2007, p. 1). However, peer tutoring has been shown widely beneficial to students from diverse backgrounds, ages, and at different levels of skill and knowledge (Weiss, 2007, p. 1). In general, tutorial behavior that gets students to generate their own explanations tends to be the most efficacious for better learning (VanLehn, Siler, Murray, Yamauchi, \& Baggett, 2003).

Studies on peer and cross-age tutoring show that both the tutors and the tutees show academic and attitudinal improvements as a result of their participation in the tutoring process. Not only are students tutored benefit, but also the students do the tutoring benefit often more than those who are being tutored. Finally, this study was conducted in the hope of identifying a cross-age online peer tutoring as another viable solution to this common problem.

\section{The Purpose and Questions of the Study}

Studies on the attitudes of students towards using a cross-age online tutoring are somehow limited. Cross-age online tutoring has become an important tool in students' education. According to Muscott (2001), cross-age tutoring gives students who have emotional and behavioral problems the opportunity to work with younger students in an effort to improve the younger students' competence in a particular subject matter. Not only do students have the opportunity to share their talents through this process, but they also have the chance to practice important social skills. At the same time, there is a slower rate of cross-age online tutoring adoption among students in Saudi Arabia.

The reason for measuring students' attitudes towards the use of cross-age online tutoring is related to the fact that students' attitudes may affect their success in the actual use of cross-age online tutoring for their academic lives. The research concentrated on answering the following questions:

(1) What are the attitudes towards using across-age online tutoring for learning purposes among tutees (usefulness, satisfaction and enjoyment)?

(2) Are there any differences in the attitudes of tutees according to their specializations and academic levels?

(3) What are the commonly held opinions on using a cross-age online tutoring for learning purposes among tutors?

\section{Method}

The idea is to provide some support for the information and communication technology which serves the computer education course (250-curriculum instruction) required for the students in their study. This support 
provides less knowledgeable students with important knowledge (students specializing in computer education). The material provided is determined based on the results of a primary survey, an interview via e-mail and various means of communication. An Internet forum was used to allow tutors to share ideas and challenges with their students. The project period extended over two semesters for the year 2010-2011. Initially, the tutors did not communicate with the tutees face to face. However, they communicated through e-mail and mobile. Then, the tutors used Facebook, online chat, mobile, YouTube and Wikis to commutate with tutees to share and publish the lessons, and activities, tasks, and handouts for tutees.

\section{Data Instruments and Data Collection}

A descriptive model, being one of the basic research methods, was used in order to determine the attitudes of tutees and tutors at King Saud University towards using a cross-age online tutoring. The data of the study were collected by means of electronic surveys and interviews. E-surveys were developed by researchers and reviewed by experts. The use of surveys is common to determine the attitudes of various populations and samples of populations (Vest, 2009). According to Neuman (2003), the following six categories of information can be obtained through surveys: (1) behavioral traits; (2) attitudes and beliefs; (3) characteristics of a sample population; (4) expectations; (5) self-classification; and (6) personal knowledge. In this study, we are concerned with attitudes, because they are the main factor in adopting innovative technologies (Vishwanath, Brodsky, Shaha, Leonard, \& Cimino, 2009). The interviews were carried out a two-week period. A structured interview was used. The questions focused on using a cross-age online tutoring for learning purposes among tutors.

The data collection to address the research questions consisted of 32 questions in electronic surveys targeting the tutees. The items in the survey were divided into two parts. The first part dealt with student's demographical data that included four items to obtain information about the students' academic specialization, frequency of using the Internet, their possession of computers and their academic levels. The second part included items that attempted to understand students' attitudes that focused on their perceptions of the usefulness of, and satisfaction with and enjoyment of a cross-age online tutoring.

The questions were constructed on a Likert-type scale consisting of five options: "Strongly disagree", “Disagree”, “Neutral”, “Agree” and "Strongly agree”. Five gradients were corrected as follows: 0, 1, 2, 3 and 4. The researcher also considered that the element has a positive attitude when the arithmetic average is 3.00 and above, and when the arithmetic average is between 2.00 and 3.00, it is a neutral attitude, while 2.00 or less is considered as a negative attitude. The interviews gave tutors open-ended questions that were dealt with topics related to their opinions. The Cronbach's alpha reliability coefficient of this study was found to be 0.95 , which means that it is an appropriate reliability coefficient to test the reliability of the scale. The data were then analyzed and interpreted by means of SPSS (Statistical Package for the Social Sciences) statistics. Therefore, the data were analyzed through frequency, mean, percentage and standard deviation 
values using descriptive statistics. In the analysis of data, one-way ANOVA was used in order to determine whether there is a significant difference in students' attitudes towards using a cross-age online tutoring as regards their academic specialization and academic levels as there are more than two levels of frequency. Therefore, the validity and reliability of this scale were ensured.

The face validity and content validity of the survey and interview form were assessed individually by three experts in the field of educational technology. Cronbach's alpha reliability analysis was adopted to test the internal consistency of the variables of the survey.

Table 1

Reliability Assessment of the Survey

\begin{tabular}{llc}
\hline Variable & Cronbach alpha $(\alpha)$ & $N$ of item \\
\hline Usefulness & 0.88 & 9 \\
Satisfaction & 0.89 & 13 \\
Enjoyment & 0.81 & 6 \\
All & 0.95 & 28 \\
\hline
\end{tabular}

Table 1 displays the Cronbach’s alpha reliability value of all the research variables. The Cronbach’s alpha values were 0.88 for usefulness, 0.89 for satisfaction, 0.81 for enjoyment and 0.95 for all. The results of the Cronbach's alpha for the scale reliabilities were extraordinarily high and indicated that the items for each scale were internally consistent and reliable.

\section{Population and Sample}

The population of the study was students at the College of Education at King Saud University in Saudi Arabia. First, there are the students taking the CI250-Computer Education Course, which is a required course for all undergraduate students at the College of Education. Second, there are the students taking the CI571-Computer Assisted Instruction Course, which is also a required course for postgraduate students in the computer education master's degree program. The sample of the study consisted of 47 students. A total of 30 (61\%) undergraduate students representing and 17 (39\%) postgraduate students representing participated in the study and were used as the sample of the study. They were intentionally selected for the study, because they could contribute to the understanding of the cross-age online tutoring.

\section{Findings and Results}

Tutees were asked to fill out an e-survey and tutors were asked to write their opinions about a cross-age online tutoring for learning purposes after two months.

The results are based on the survey responses of 30 participants. Table 2 depicts the distribution of the characteristics of the students of the study. Those academic levels between (3-4) levels form the largest group of all (46.7\%), followed by those between (1-2) levels and (5-6) levels (20.0\%), and those (7-8) levels (13.3\%). 
According to this analysis, five (16.7\%) students enrolled in Islamic Study, 18 (60.0\%) students enrolled in special education and seven (23.3\%) students enrolled in other courses. Ninety three point three percent have computers and $6.7 \%$ do not have computers. Finally, $36.7 \%$ of the participants use the Internet for less than an hour a day and $40.0 \%$ of the participants use it for one to three hours a day, while $23.3 \%$ use it for more than three hours a day.

Table 2

Demographics of the Study Sample

\begin{tabular}{llcc}
\hline & Characteristic & Frequency & Percentage (\%) \\
\hline \multirow{3}{*}{ Academic level } & $(1-2)$ & 6 & 20.0 \\
& $(3-4)$ & 14 & 46.7 \\
& $(5-6)$ & 6 & 20.0 \\
& $(7-8)$ & 4 & 13.3 \\
\hline \multirow{3}{*}{ Specialization } & Islamic culture & 5 & 16.7 \\
& Special education & 18 & 60.0 \\
Having a computer & Other & 7 & 23.3 \\
\hline \multirow{2}{*}{ Internet use in the day } & Yes & 28 & 93.3 \\
& No & 2 & 6.7 \\
\hline
\end{tabular}

Table 3

Shows the Differences in Attitudes According to Specializations

\begin{tabular}{llclll}
\hline & & Sum of square & Mean square & $F$-ratio & Sig. \\
\hline \multirow{3}{*}{ Usefulness } & Between groups & 0.925 & 0.463 & 1.133 & 0.337 \\
& Within groups & 11.024 & 0.408 & & \\
& Total & 11.949 & & 2.099 & 0.142 \\
Satisfaction & Between groups & 1.413 & 0.707 & & \\
& Within groups & 9.092 & 0.337 & 0.823 \\
& Total & 10.505 & & 0.196 & 0.253 \\
\hline \multirow{3}{*}{ Enjoyment } & Between groups & 0.135 & 0.067 & & \\
& Within groups & 9.312 & 0.345 & & \\
& Total & 9.447 & & & \\
\hline
\end{tabular}

To examine the differences in students' attitudes towards using a cross-age online tutoring according to their specializations, the one-way ANOVA test was conducted. There is no statistically significant difference in the students' attitudes towards using a cross-age online in terms of usefulness, satisfaction, enjoyment, and overall (see Table 3). 
To examine the differences in students' attitudes towards using a cross-age online tutoring according to their academic levels, the one-way ANOVA test was conducted. There is no statistically significant difference in the students' attitudes towards using a cross-age online in terms of satisfaction, usefulness, enjoyment and overall (see Table 4).

Table 4

Shows the Differences in Attitudes According to Academic Levels

\begin{tabular}{|c|c|c|c|c|c|}
\hline & & Sum of squares & Mean square & $F$-ratio & Sig. \\
\hline & Between groups & 1.032 & 0.344 & 0.819 & 0.495 \\
\hline \multirow[t]{3}{*}{ Usefulness } & Within groups & 10.917 & 0.420 & & \\
\hline & Total & 11.949 & & & \\
\hline & Between groups & 1.602 & 0.534 & 1.560 & 0.223 \\
\hline \multirow[t]{3}{*}{ Satisfaction } & Within groups & 8.903 & 0.342 & & \\
\hline & Total & 10.505 & & & \\
\hline & Between groups & 1.217 & 0.406 & 1.281 & 0.302 \\
\hline \multirow[t]{3}{*}{ Enjoyment } & Within groups & 8.230 & 0.317 & & \\
\hline & Total & 9.447 & & & \\
\hline & Between groups & 1.292 & 0.431 & 1.246 & 0.313 \\
\hline \multirow[t]{2}{*}{ Overall } & Within groups & 8.990 & 0.346 & & \\
\hline & Total & 10.282 & & & \\
\hline
\end{tabular}

Table 5

The Internal Consistency Reliability

\begin{tabular}{|c|c|c|c|c|c|c|c|c|}
\hline$N$ & \multicolumn{2}{|c|}{ Satisfaction } & $N$ & \multicolumn{2}{|c|}{ Usefulness } & $N$ & \multicolumn{2}{|c|}{ Enjoyment } \\
\hline \multirow[t]{2}{*}{ c2 } & $\begin{array}{l}\text { Pearson } \\
\text { correlation }\end{array}$ & $0.693^{* *}$ & \multirow[t]{2}{*}{ c1 } & \begin{tabular}{|l|} 
Pearson \\
correlation
\end{tabular} & $0.833^{* *}$ & \multirow[t]{2}{*}{ c18 } & $\begin{array}{l}\text { Pearson } \\
\text { correlation }\end{array}$ & $0.612^{* *}$ \\
\hline & Sig. (2-tailed) & 0.000 & & Sig. (2-tailed) & 0.000 & & Sig. (2-tailed) & 0.000 \\
\hline \multirow[t]{2}{*}{ c3 } & $\begin{array}{l}\text { Pearson } \\
\text { correlation }\end{array}$ & $0.645^{* *}$ & \multirow[t]{2}{*}{ c5 } & $\begin{array}{l}\text { Pearson } \\
\text { correlation }\end{array}$ & $0.750^{* *}$ & \multirow[t]{2}{*}{ c19 } & $\begin{array}{l}\text { Pearson } \\
\text { correlation }\end{array}$ & $0.705^{* *}$ \\
\hline & Sig. (2-tailed) & 0.000 & & Sig. (2-tailed) & 0.000 & & Sig. (2-tailed) & 0.000 \\
\hline \multirow[t]{2}{*}{ c4 } & $\begin{array}{l}\text { Pearson } \\
\text { correlation }\end{array}$ & $0.741^{* *}$ & \multirow[t]{2}{*}{ c6 } & $\begin{array}{l}\text { Pearson } \\
\text { correlation }\end{array}$ & $0.730^{* *}$ & \multirow[t]{2}{*}{ c20 } & $\begin{array}{l}\text { Pearson } \\
\text { correlation }\end{array}$ & $0.693^{* *}$ \\
\hline & Sig. (2-tailed) & 0.000 & & Sig. (2-tailed) & 0.000 & & Sig. (2-tailed) & 0.000 \\
\hline \multirow[t]{2}{*}{ c7 } & $\begin{array}{l}\text { Pearson } \\
\text { correlation }\end{array}$ & $0.649^{* *}$ & \multirow[t]{2}{*}{ c9 } & $\begin{array}{l}\text { Pearson } \\
\text { correlation } \\
\end{array}$ & $0.674^{* *}$ & \multirow[t]{2}{*}{ c26 } & \begin{tabular}{|l|} 
Pearson \\
correlation \\
\end{tabular} & $0.739^{* *}$ \\
\hline & Sig. (2-tailed) & 0.000 & & Sig. (2-tailed) & 0.000 & & Sig. (2-tailed) & 0.000 \\
\hline \multirow[t]{2}{*}{ c8 } & $\begin{array}{l}\text { Pearson } \\
\text { correlation }\end{array}$ & $0.771^{* *}$ & \multirow[t]{2}{*}{ c15 } & $\begin{array}{l}\text { Pearson } \\
\text { correlation }\end{array}$ & $0.754^{* *}$ & \multirow[t]{2}{*}{ c27 } & $\begin{array}{l}\text { Pearson } \\
\text { correlation }\end{array}$ & $0.692^{* *}$ \\
\hline & Sig. (2-tailed) & 0.000 & & Sig. (2-tailed) & 0.000 & & Sig. (2-tailed) & 0.000 \\
\hline \multirow[t]{2}{*}{ c10 } & $\begin{array}{l}\text { Pearson } \\
\text { correlation }\end{array}$ & $0.724^{* *}$ & \multirow[t]{2}{*}{ c16 } & $\begin{array}{l}\text { Pearson } \\
\text { correlation }\end{array}$ & $0.848^{* *}$ & \multirow[t]{2}{*}{ c28 } & $\begin{array}{l}\text { Pearson } \\
\text { correlation }\end{array}$ & $0.652^{* *}$ \\
\hline & Sig. (2-tailed) & 0.000 & & Sig. (2-tailed) & 0.000 & & Sig. (2-tailed) & 0.000 \\
\hline \multirow[t]{2}{*}{ c11 } & $\begin{array}{l}\text { Pearson } \\
\text { correlation }\end{array}$ & $0.468^{* *}$ & \multirow[t]{2}{*}{ c22 } & $\begin{array}{l}\text { Pearson } \\
\text { correlation }\end{array}$ & $0.720^{* *}$ & & & \\
\hline & Sig. (2-tailed) & 0.009 & & Sig. (2-tailed) & 0.000 & & & \\
\hline
\end{tabular}


(Table 5 continued)

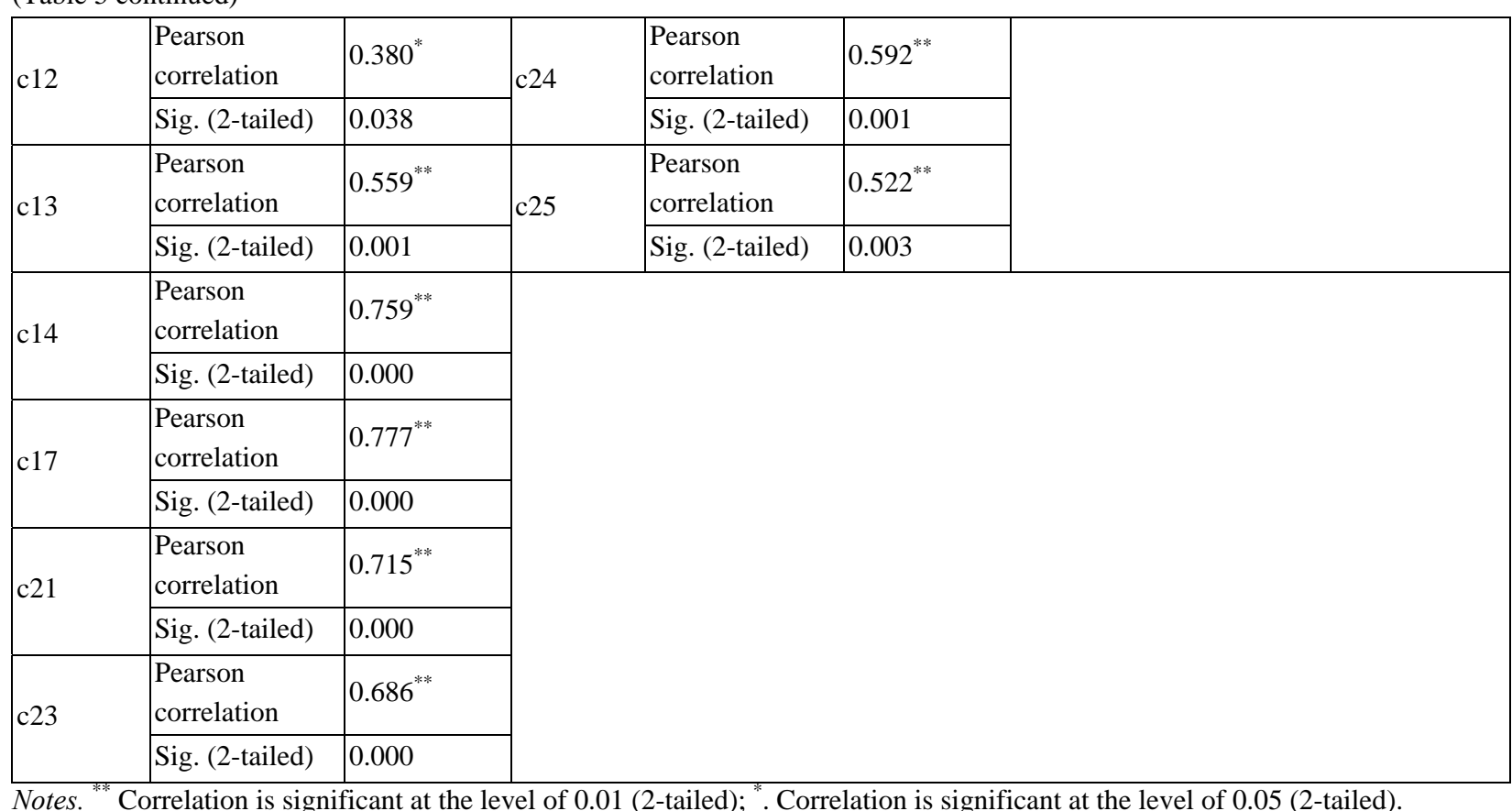

Do the students have positive attitudes towards usefulness? This question was answered by making reference to Table 6 .

Table 6

Attitudes Towards Usefulness

\begin{tabular}{llllllllll}
\hline Item & 1 & 5 & 6 & 9 & 15 & 16 & 22 & 24 & 25 \\
\hline Arithmetic mean & 3.25 & 3.11 & 3.29 & 3.21 & 3.00 & 3.29 & 3.14 & 2.96 & 3.39 \\
\hline
\end{tabular}

Table 6 reveals that arithmetic means range from 2.96 to 3.39, and that almost all items have positive attitudes. The highest one is 3.39, which means that tutor shave a positive impact on the educational process and teaching methods, while the lowest one is 2.96 , which means that tutors are more precise, patient and careful in the selection of the required information. From the results obtained, there is an indication that these tutors have positive attitudes towards online tutoring in terms of usefulness.

Table 7

Attitudes Towards Satisfaction

\begin{tabular}{|c|c|c|c|c|c|c|c|c|c|c|c|c|c|}
\hline Item & 2 & 3 & 4 & 7 & 8 & 10 & 11 & 12 & 13 & 14 & 17 & 21 & 23 \\
\hline Arithmetic mean & 3.25 & 2.96 & 3.00 & 3.46 & 3.25 & 3.36 & 3.11 & 2.96 & 3.46 & 3.14 & 3.21 & 2.82 & 2.96 \\
\hline
\end{tabular}

Table 7 reveals that that arithmetic means range from 2.82 to 3.46, which indicates a positive attitude on average. Two items have maximum positive attitudes. Tutors feel that online tutoring helps make scientific and technical progress and helps in the identification of new technologies, while three items have neutral 
attitudes. The lowest one about online tutoring is when tutors feel unsure about the usefulness of computers in education

From the results obtained, we can notice that there is an indication that these tutors have positive attitudes towards online tutoring in terms of satisfaction.

Table 8

Attitudes Towards Enjoyment

\begin{tabular}{lllllll}
\hline Items & 18 & 19 & 20 & 26 & 27 & 28 \\
\hline Arithmetic mean & 3.25 & 3.18 & 2.86 & 2.86 & 2.96 & 3.39 \\
\hline
\end{tabular}

From the analysis of Table 8, we find that arithmetic means range from 2.86 to 3.39. The highest two items are 3.25 and 3.39. The mean 3.39 shows that online tutoring helps form positive relationships with the others and the mean 3.25 shows that tutors hope to be tutors in the future. From the results obtained there, we notice that there is an indication that these tutors have positive attitudes towards online tutoring in terms of enjoyment.

Table 9

Attitudes Towards Online Tutoring (Overall)

\begin{tabular}{ll}
\hline Items & Mean \\
\hline Usefulness & 3.18 \\
Satisfaction & 3.15 \\
Enjoyment & 3.08 \\
Overall & 3.14 \\
\hline
\end{tabular}

Table 9 reveals that the overall arithmetic mean is 3.14, which shows that these students have positive attitudes towards online tutoring.

From the results of the interviews, we find that all tutors enjoy using a cross-age online tutoring for learning purposes. All of them strongly agree that:

(1) Cross-age online tutoring helped students to learn;

(2) Cross-age online tutoring gave students good suggestions on their problems;

(3) Cross-age online tutoring is trustworthy;

(4) They never had a time that they felt uncomfortable;

(5) Cross-age online tutoring can take place anywhere and at anytime;

(6) There is a possibility of an ongoing follow-up of the level of their educational progress and skills;

(7) It is easy to discover the flaw inherent in the capabilities and potential of students;

(8) There is a possibility that the students to benefit from each other and inspire competition among them;

(9) Students can be tested on basic computer skills and that there is more than one way in which students 
communicate with each other;

(10) Tutors can provide basic skills in the computer through traditional lectures and then gradually move to the style of online tutoring;

(11) Online tutoring should preferably be conducted with a homogeneous group of students who have equal skills scientifically and culturally.

\section{Conclusions and Suggestions}

The success of the implementation of online tutoring at the College of Education depends on students' attitudes. The aim of the present study was to identify the attitudes of the tutees and the opinions of the tutors at King Saud University towards using a cross-age online tutoring as opposed to the traditional classroom environment.

A second goal was to find out if there are any differences in the attitudes of both the tutees and tutors to online tutoring according to their specializations and academic levels. As a result, it has been found that students' attitudes towards a cross-age online tutoring are positive, indicating that the majority of the students accepted the use of a cross-age online tutoring for learning purposes. The results also revealed that their attitudes to online tutoring according to their specializations and academic levels did not differ.

The tutors were asked to give their opinions and they said that the students were more respectful. They also mentioned some notable advantages of a cross-age online tutoring.

During the interviews, all the participants reported that they were familiar with the use of online tutoring. The results of both the surveys and the interviews revealed that the students' need of online tutoring will definitely increase.

The present study offered an important implication for the future professional development programs to prepare students to use a cross-age online tutoring for educational purposes. As a result of this study, the following recommendations can be made:

(1) Students should be motivated to develop their online tutoring skills;

(2) Students should be encouraged to make use of the online tutoring as a learning tool;

(3) Future researchers need to consider the in-depth qualitative studies on online tutoring;

(4) It is recommended that further research be done at various institutions and at various educational levels to confirm the results of this study;

(5) More research is needed to support these findings.

\section{References}

Auxter, L. (2007). Acquisition of sight words using peer tutoring. Retrieved March 30, 2010, from http://www.search.proquest. com/docview/304704620/fulltextPDF/1362B3E8CC61C439EA2/1?accountid=44936

Bonk, C., Wisher, R., \& Lee, J. (2004). Moderating learner centered e-learning: Problems and solutions, benefits and implications. In T. S. Roberts (Ed.), Online collaborative learning: Theory and practice (pp. 54-85). Hershey, USA: Information Science Publishing. 
Cairo, L., \& Craig, J. (2005). Cross-age tutoring: Phase II, an experiment. Technical Report. Appalachia Educational Laboratory at Edvantia. Retrieved June 15, 2011, from http://www.eric.ed.gov/PDFS/ED489129.pdf

de Vries, F., Kester, L., Sloep, P. B., van Rosmalen, P., Pannekeet, K., \& Koper, R. (2005). Identification of critical time-consuming student support activities in e-learning. Retrieved May 2, 2010, from http://www.scribd.com/doc/ 14986/Online-Learning -Supportthrough-Peer-Tutoring-OpenUniversiteitNederland-2006

Denis, B. (2003). What roles and what training for tutors involved in training devices remotely? Distances and Knowledge, 1, 24-29.

Denis, B., Watland, P., Pirotte, S., \&Verday, N. (2004). Roles and competencies of the e-tutor. Paper presented at the Networked Learning Conference 2004. Lancaster: Lancaster University, April 5-7, 2004.

Gaustad, J. (1993). Peer and cross-age tutoring. Retrieved March 28, 2010, from http://www.scholarsbank.uoregon.edu/jspui/ bitstream/1794/3300/1/digest079.pdf

Jones, R. H., Garralda, A., Li, D. C. S., \& Lock, G. (2006). Interactional dynamics in on-line and face-to-face peer-tutoring sessions for second language writers. Journal of Second Language Writing, 15, 1-23.

Jung, I., Choi, S., Lim, C., \& Leem, J. (2002). Effects of different types of interaction on learning achievement, satisfaction and participation in web-based instruction. Innovations in Education and Teaching International, 39, 153-162.

Kalkowski, P. (2001). Peer and cross-age tutoring (School Improvement Research Series). Retrieved March 30, 2009, from http://www.nwrel.org/scpd/sirs/9/c018.html

Lentell, H. (2003). The importance of the tutor in open and distance learning. In A. Tait, \& R. Mills (Eds.), Rethinking learner-support in distance education (pp. 64-76). London: RoutledgeFalmer Press.

McLuckie, J. \& Topping, K. J. (2004). Transferable skills for online peer learning. Assessment and Evaluation in Higher Education, 29, 563-584.

Muscott, H. (2001). An introduction to service-learning for students with emotional and behavioral disorders: Answers to frequently asked questions. Beyond Behavior, 10(3), 8-15.

National Tutoring Association. (2010). Peer tutoring factsheet. Retrieved December 15, 2010, from http://crossroadsoflearning. com/nta-tutorpalooza/pdf/NTA_Peer_Tutoring_Factsheet_020107.pdf

Neuman, W. (2003). Social research methods (5th ed.). Boston: Allyn and Bacon.

Prensky, M. (2002). E-Nough! Retrieved January 11, 2010, from http://www.marcprensky.com/writing/Prensky\%20-\%20e-Nough \% 20-\%20OTH\%2011-1\%20March\%202003.pdf

Smet, M. (2008). Online peer tutoring behavior in a higher education context. Retrieved April 15, 2010, from http://www. peersupport.nl/Media/view/35111/proefschrift_8jan8\%20MdeSmet.pdf

Teles, L., Ashton, S., Roberts, T., \& Tzoneva, I. (2001). The role of the instructor in e-learning collaborative environments. Retrieved March 30, 2009, from http://www.telestraininglobal.com/press/media/techknowlo.article.pdf

Thompson, C. N. (2007). Attitudes of Western Pennsylvania teachers towards peer tutoring in technology instruction and integration. Retrieved March 30, 2010, from http://www.gradworks.umi.com/32/67/3267739.html

Topping, K. J. (1996). The effectiveness of peer tutoring in further and higher education: A typology and review of the literature. Higher Education, 32, 321-345.

Topping, K. J. (1998). The effectiveness of peer tutoring in further and higher education: A typology and review of the literature. In S. Goodlad (Ed.), Mentoring and tutoring by students. London: Kogan Page.

Topping, K. J., \& Ehly, S. (Eds.). (1998). Peer-assisted learning. Mahwah, N. J.: Lawrence Erlbaum.

UKCME (UK Center for Materials Education). (2011). Using students as peer tutors or assessors. The Higher Education Academy. Retrieved January 11, 2010, from http://www.materials.ac.uk/pub/Peer-tutors.pdf

VanLehn, K., Siler, S., Murray, C., Yamauchi, T., \& Baggett, W. B. (2003). Why do only some events cause learning during human tutoring? Cognition and Instruction, 21, 209-249.

Vest, S. L. (2009). Determining attitudes and opinions of adjunct instructors who teach online and in traditional classroom classes. D.B.A., University of Phoenix.

Vishwanath, A., Brodsky, L., Shaha, S., Leonard M., \& Cimino, M. (2009). Patterns and changes in prescriber attitudes toward PDA prescription-assistive technology. International Journal of Medical Informatics, 78(5), 330-339.

Webb, M. (1987). Peer helping relationships in urban schools. ERIC Digest. New York, N. Y..

Weiss, R. (2007). Academic tutoring: A review for Cypress College. Retrieved December 11, 2010, from http://www. cypresscollege.edu/IRP/Resources/Research/SE/TutoringLiteratureReview.pdf 